\title{
THE ROLE OF EARNINGS MANAGEMENT: TAX PLANNING AND PROFITABILITY WITH PERMANENT DIFFERENCE AND TEMPORARY DIFFERENCE AS MODERATING VARIABLES ON INDONESIAN STOCK EXCHANGE-LISTED MANUFACTURING COMPANIES
}

\author{
Sriloka Yuliani \\ Master's Program in Management, Faculty of Economics and Business, \\ University of Esa Unggul, Indonesia \\ E-mail: yulianisriloka8@gmail.com
}

\begin{abstract}
This study aimed to analyze the effect of tax planning and profitability on earnings management with permanent differences and temporary differences as moderating variables. Tax planning was measured by the ratio of total tax paid to total Earning Before Tax (EBT), and profitability was calculated based on profit per period. Furthermore, earnings management was measured based on the ratio of total net income $(\mathrm{t})$ minus total earning (t1) to Market Value Equity (t-1). Permanent differences were calculated based on the ratio of total permanent differences to total assets. In contrast, temporary differences were measured based on the ratio of total temporary differences to total assets. The sample in this research included 65 manufacturing companies listed on the 2017-2018 Indonesian Stock Exchange. The statistical method employed in this research was multiple regression analysis. The results showed that tax planning had a significant negative effect on earnings management; permanent differences did not moderate the effect of tax planning and profitability on earnings management, and temporary differences moderated the effect of tax planning and profitability on earnings management.
\end{abstract}

\section{KEY WORDS}

Tax planning, profitability, earnings management, permanent difference, temporary difference.

Profits are a management assertion whose quality needs to be proven where profit information in financial statements is used to make investment decisions (Hotimah, 2015). In external financial statements, management intervention is done by performing earnings management to smooth, increase, and decrease profits (Schipper, 1989 dan Gunawan et al., 2015). The concept of earnings management can be explained using the agency theory and positive accounting theory. The objectives of earnings management can be bonuses, tax motivation, leadership change, and initial public offerings. Initial public offerings refer to a condition where a company receives internal and external sources of funds. Managers need the capital structure to determine corporate capital fulfillment using their capital or foreign capital (Munandar, 2014).

The decision taken by managers to perform earnings management is referred to as financial statements (Kasmir, 2015). In the financial statement, a recording process is carried out regularly to collect financial data and information by taking into account the corporate risk management, both internal and external (Law Number 26 Article 1 concerning General Tax Provision; Munandar et al., 2018; Limbong et al., 2019). In making financial statements, the government also stipulates accounting reports following Government Accounting Standards and Law No. 17 of 2003 concerning State Finance (Ramdhani, 2016).

Profitability, or the level of profit in a company, results from a manager's performance. Low or high profitability will cause managers to perform earnings management to smooth income. Income smoothing is one way to reduce the variability of reported total profits to match the desired target (Koch, 1981; Rasinih \& Munandar, 2016). Improving the quality of auditing financial statements is one way to reduce the practice of income smoothing. 
According to Sunaryanto \& Syah (2018), there must be a tool in the accounting process to minimize errors in cost items that tend to fraud or waste.

Agustina et al. (2018) explained the relevance of earnings management to profitability. Managers could manipulate profit information to improve corporate reputation when corporate profits are low, with theoretical studies including leverage ratios, company size, and corporate governance.

Tax Planning is one of the functions of tax management. Through tax planning, companies can suppress tax payment as minimum as possible by legal means (Herawati \& Ekawati, 2016). To meet tax reporting needs, companies need to make fiscal corrections, covering negative and positive corrections. What a taxpayer needs to do is to correct income and expenses following existing tax regulations.

The difference between income before tax (pre-tax income) and taxable income can be categorized into permanent differences and temporary differences. Book-Tax Differences are used as a diagnosis that the big difference between accounting profit (income before tax) and fiscal profit (taxable income) indicates manipulation of the main cost and is a "Red Flag" for users of financial statements (Amelia \& Yudianto, 2016).

Hotimah (2015) studies the effect of tax planning on earnings management measured by discretionary accrual and tax planning proxies with effective tax rates. Furthermore, Purnamasari (2019) studied the effect of Deferred Tax Expenses and Tax Planning on Earnings Management. However, studies on the effect of profitability on earnings management by adding a book-tax difference as a moderating variable have never been carried out; thus, further studies are needed.

This research is expected to be a reference for scientific studies on the effect of tax planning and profitability on earnings management, each moderated by permanent differences and temporary differences. The present study is also expected to provide information and descriptions to investors and other parties based on the variables.

\section{LITERATURE REVIEW}

\section{Earnings Management}

The information in profits has a significant role for the interested parties of the company. It becomes the basis for decision-making, such as providing compensation, bonus distribution, assessment of achievement and management performance, the imposition of taxes for internal and external parties using profits (Prasetyorini, 2013).

Earnings management is a managerial activity to influence financial reports either by manipulating corporate financial data or information or selecting accounting methods accepted in general accounting principles, ultimately aiming to gain corporate profits (Aditama \& Purwaningsih, 2016).

According to Watts and Zimmerman (2006), there are three (3) hypotheses in the positive accounting theory: bonus plans, debt covenants, and political costs. The bonus plan hypothesis explains that the manager transfers future income to the income to get bonuses using the applicable accounting procedures. Meanwhile, in the debt covenant hypothesis states that the future income is transferred to the present to increase net income for companies that will violate debt covenants. Lastly, the political cost hypothesis states that if the profitability is high, the company tends to shift its income to avoid political costs. Political costs include all costs to be borne in connection with government regulations, tax rates, and labor demands.

\section{Profitability}

A company's level of net income in carrying out its operation is also called profitability. When associated with earnings management, profitability is a manager's attempt to show the best performance of the company he leads. If the profitability is low, the manager will carry out earning managements to smooth income.

Companies can maximize profits by knowing what factors affect profitability. Each factor needs asset management, cost management, and debt management (Fahmi \& 
Saputra, 2013). The factors influencing profitability are the capital structure, company size, liquidity, and working capital turnover. Profitability can be measured using the Return on Asset (ROA). The profitability ratio also measures the level of corporate management effectiveness as indicated by the profit generated from sales and investment income (Agustina et al., 2018).

\section{Tax Planning}

In tax management, the first step is tax planning. It continues with collecting and conducting research on existing tax regulations to select tax savings measures to be taken by the management.

The difference between accounting standards and tax provisions requires management to prepare two kinds of financial reports at the end of each period, namely business financial reports and fiscal financial reports. Tax liabilities are minimized by suppressing tax planning to maximize earnings (Herawati \& Ekawati, 2016). This difference is caused by differences in interests between commercial accounting, which bases profit on the basic concept of accounting, which matches costs against revenue. Meanwhile, from a fiscal perspective, the main objective is state revenue. In preparing fiscal financial reports, taxpayers must refer to the Taxation Regulation Law Number 36 regarding Income Tax. Business financial reports prepared based on Financial Accounting Standards must be adjusted or fiscally corrected before calculating the amount of taxable income.

\section{Book-Tax Differences}

The difference between commercial (accounting) profit and fiscal profit is called booktax differences. Hanlon (2005) stated that taxable income could be used as a benchmark for evaluating accounting profit. Permanent differences arise when the calculation of fiscal profit is different from the calculation of profit according to Financial Accounting Standards, resulting in positive or negative corrections. Moreover, permanent differences come from non-taxable income or income liable to a final tax and non-deductible expenses. In general, permanent differences occurring due to differences in recognition of income and expenses are explained in Law Number 36 of 2008 Article 4 Paragraph (3), Article 9 Paragraph (1) and (2), and Article 18 (Brolin \& Rohman, 2014).

Meanwhile, differences in recognition timing and methods of income and expenses between tax regulations and Financial Accounting Standards are called temporary differences, resulting in differences in the recognition timing of income and expenses from one to the next tax year (Amelia \& Yudianto, 2016 \& Suandy, 2011).

According to the Institute of Indonesia Chartered Accountants in Statements of Financial Accounting Standards (SFAS) Number 46 (reformatted in 2007) on Income Tax Accounting Paragraph 7, temporary differences can be in the form of taxable temporary differences causing taxable amounts in the fiscal reports of the upcoming period, provided that the carrying value of the assets is recovered or the carrying value of the liability is settled. Also, deductible temporary differences cause deductible amounts in the fiscal reports of the upcoming period, provided that the carrying value of the assets is recovered or the carrying value of the liability is settled (Amelia \& Yudianto, 2016).

\section{Relationship between Variables}

Relationship between Tax Planning and Earnings Management

Tax liabilities are minimized by emphasizing tax planning to maximize profits (Herawati \& Ekawati, 2016). After managers carry out tax planning, the next stages are conducting research and collecting tax regulations to select tax savings measures to be carried out and desired by the management.

Hotimah (2015) revealed that tax planning negatively affected earnings management. Likewise, Hapsari \& Manzilah (2016) proved that planning negatively affected earnings management.

$\mathrm{H}_{1}$ : Tax Planning negatively affects earnings management. 


\section{Relationship between Profitability and Earnings Management}

Profitability supposedly affects earnings management. It is based on the financial management theory stating that corporate earnings in one period or one year trigger corporate managers to carry out earnings management to provide the best economic decision. What underlies this decision is the measurement of financial statement components carried out over several periods of the company's operating time to see the corporate development over a certain period. The results of the corporate development obtained will be used as a management performance evaluation tool (Agustina et al., 2018)

Furthermore, Gunawan (2015) \& Riska (2019) suggest that profitability has a positive and significant effect on earnings management.

$\mathrm{H}_{2}$ : Profitability positively affects earnings management.

Relationship between Tax Planning and Earnings Management Moderated by Permanent Differences

Tax planning is one of the earnings management for external financial reports. The difference between commercial or business and fiscal financial reports can be grouped into permanent differences and temporary differences. Book-tax differences can be used to detect the existence of earnings management due to a little accounting freedom allowed in measuring taxable income (Sari \& Purwaningsih, 2016). Permanent differences come from non-taxable income or income liable to a final tax and non-deductible expenses (Amelia \& Yudianto, 2016 \& Suandy, 2011).

$\mathrm{H}_{3}$ : Permanent difference negatively moderates the relationship between Tax Planning and Earnings Management.

Relationship between Tax Planning and Earnings Management Moderated by Temporary Differences

Temporary differences cause both negative and positive fiscal corrections that can be used to minimize an entity's payable income tax by performing tax planning (Amelia \& Yudianto, 2016 \& Suandy, 2011). The difference between the tax base of an asset or liability and the asset's carrying value results in an increase or decrease in future taxable income (Brolin \& Rohman, 2014). The increase or decrease in fiscal profit will affect the existing earnings management and tax planning in the upcoming period.

$\mathrm{H}_{4}$ : Temporary difference moderates the relationship between Tax Planning and Earnings Management

Relationship between Profitability and Earnings Management Moderated by Permanent Difference

The managers' performance can be seen from the profitability of the company they lead. Managers can also perform income smoothing if the corporate profit is low. A company with a large profit does not rule out earnings management practices if it has no effective corporate governance system (Agustina et al., 2018). Permanent differences result from nontaxable income or income liable to a final tax and non-deductible expenses (Amelia \& Yudianto, 2016 \& Suandy, 2011).

$\mathrm{H}_{5}$ : Permanent difference negatively moderates the relationship between profitability and earnings management.

Relationship between Profitability and Earnings Management Moderated by Temporary Difference

Based on previous theories and studies on profitability and its influence on earnings management, it can be concluded that profitability affects earnings management practices (Agustina 2018). Temporary differences occur due to the inequality of timing in recognizing income and expenses between tax regulations and Financial Accounting Standards. Temporary differences can be divided into positive temporary differences and negative temporary differences.

$\mathrm{H}_{6}$ : Temporary difference moderates the relationship between profitability and earnings management. 
Based on the hypotheses above, the research model is depicted in the following figure:

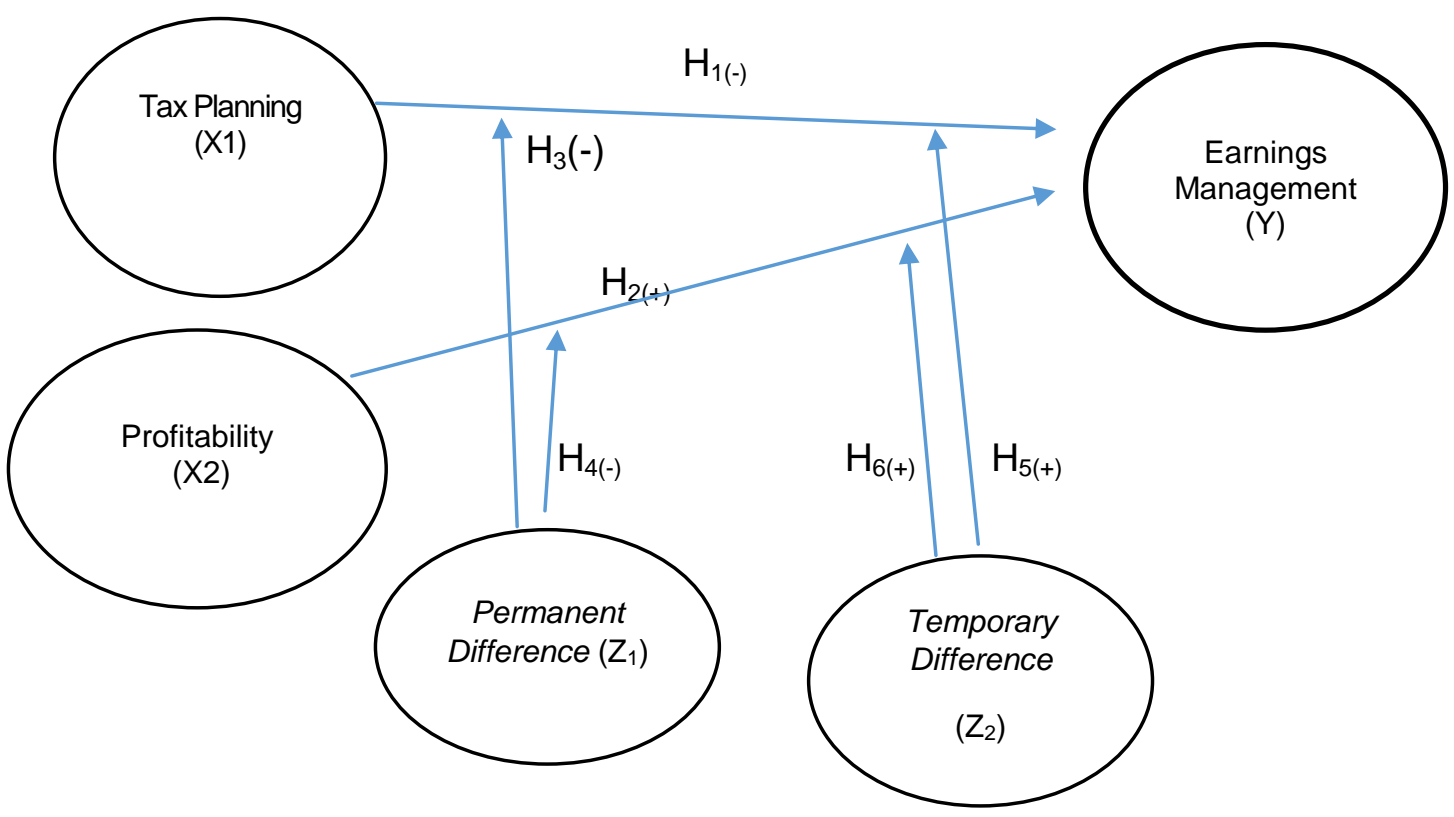

Figure 1 - Research Model

\section{METHODS OF RESEARCH}

This research aimed to examine the effect of tax planning and profitability on earnings management with book-tax differences as the moderating variable. According to Hotimah (2015) and Hapsari \& Manzilah (2016), tax planning negatively affects earnings management. On the other side, profitability positively affects earnings management (Gunawan, 2015; Riska, 2019).

This research used a quantitative approach with secondary data. The variables used in this research consisted of independent variables (Tax Planning and Profitability), a dependent variable (earnings management), and a moderating variable (Book Tax Differences). Data was collected using purposive sampling with a population of manufacturing companies listed on the Indonesia Stock Exchange (IDX). This research sample consisted of 65 manufacturing companies listed on the Indonesian Stock Exchange during 2017-2018, so the total research sample was 130 (65 companies within two years of observation).

This research focused on manufacturing companies because, based on the data from various sources, earnings management tends to be dominated by manufacturing companies. The researcher also found that, during 2011, the Indonesian Capital Market Supervisory Agency imposed sanctions on 200 issuers, 17 investment management companies, and 42 insecurities companies due to various errors, one of which was the delay in submitting periodic reports. In 2010, sanctions were imposed on four (4) issuers because the firstquarter financial statements' presentation was related to the misstatement of fund placements in the form of deposits.

Testing in this research was carried out using SPSS statistical software. Hypothesis testing employed a multiple linear regression method and pre-testing, including normality test, classical assumption test, and continued with t-test.

\section{RESULTS AND DISCUSSION}

The object of this research consisted of 130 manufacturing companies for two (2) years of observation, namely $2017-2018$ (65 companies for each year). In the data normality and classical assumption tests, it was proven that each variable had a significance level above 0.05 , meaning that the data were normally distributed and feasible for further testing. 
The normality test is used to determine whether the data taken from a population are normally distributed. In this research, the normality test using the Kolmogorov Smirnov test showed that the data used were normally distributed (asymp. sig $=0.291,>0.05$ ). Thus, the data could be used in the testing with a regression model.

A multicollinearity test is used to test whether, in the regression model, there is a correlation between the independent variables. The multicollinearity test in this research used a tolerance value and variance inflation factor (VIF). The multicollinearity test results showed that all variables' tolerance value was greater than 0.1 , and the VIF value for all variables was smaller than 10 . Thus, there are no multicollinearity symptoms found in this research.

The heteroscedasticity test aims to test whether, in the regression model, there is an inequality of variants from the residuals of one to other observations. The heteroscedasticity test in this research indicated no heteroscedasticity symptoms occurring.

Based on the results, tax planning partially correlated with earnings management with a significance value of $0.016(<0.05)$. Meanwhile, the effect of profitability on earnings management had a significance value of 0.21 with a positive correlation.

Based on the moderation test, the moderating effect of permanent differences on the relationship between tax planning and earnings management was $0.974(>0.05)$, meaning that permanent differences did not moderate the effect of tax planning on earnings management.

Likewise, the moderating effect of permanent differences on the relationship between profitability and earnings management was 0.979 (> 0.05), indicating that permanent differences also did not moderate the effect of profitability on earnings management.

On the other side, the moderation test proved that temporary differences moderated tax planning effect on earnings management, indicated by the significance value of 0.019 (< 0.05).

Besides, temporary differences showed a moderating effect on the relationship between profitability and earnings management of $0.022(<0.05)$. In other words, temporary differences moderated the effect of profitability on earnings management. From the calculation of multiple linear regression, the relationship between independent and dependent variables can be formulated as follows:

$$
M L=0,029-0,006 T P+0,008 P R-0,014 P D+0,019 T D
$$

From the above equation, a constant of 0.029 indicates that if there are no independent variables considered constant $(x 1=0, x 2=0)$, earnings management will be 0.029 . A decrease in tax planning coefficient of 0.006 indicates that a change in tax planning by $1 \%$ will reduce earnings by 0.006 or $0.06 \%$. An increase in profitability coefficient of 0.008 indicates that a change in profitability by $1 \%$ will increase earnings by $0.08 \%$. The permanent difference coefficient decreases by 0.014 , and the temporary difference increases by 0.019 .

This research confirmed the hypothesis stating that Tax Planning negatively affects earnings management. The results of this research are consistent with Hotimah (2015); Aditama \& Purwaningsih (2016), proving that tax planning negatively affects earnings management because of the increasing number of companies carrying out tax planning, not for managing earnings but to be effective and efficient with the company's operational expenses, especially in minimizing the company's tax burden with a note that it must be according to predetermined standards.

However, the results are different from Yuniati et al. (2018) \& Yunila \& Aryati (2018), proving that in minimizing the tax burden borne, the company used tax planning. It can be seen that the higher the company's earnings management, the higher the level of tax planning (Yunila \& Aryati, 2018). Determining how much profit is reported is one function of tax planning. Profit arrangements are an indication of earnings management practices (Yuniati et al., 2018).

The present study results sustained the hypothesis stating that profitability had a positive effect on earnings management. However, the results contradicted Gunawan et al. 
(2015), proving that profitability does not affect earnings management because companies with high profits will not practice earnings management to meet the interests of corporate managers and owners.

The results are also consistent with Riska (2019) and Amelia \& Hernawati (2016) that profitability positively and significantly affects earnings management. Earnings management tends to be carried out by companies when the company's profitability increases. The purpose is to maintain and gain the company's credibility so that the company will try to be seen well by external parties.

This research confirmed the hypothesis stating that permanent differences did not moderate the relationship between tax planning and earnings management. Permanent differences trigger the difference between income and expenses in financial and fiscal reporting. It occurs because there is an adjustment at the end of the period due to some expenses that cannot be included as company operating expenses, causing changes in the value of operating profit and ultimately triggering earnings management (Amelia \& Yudianto, 2016).

This research confirmed the hypothesis stating that temporary differences moderated the relationship between tax planning and earnings management because positive timing differences can occur if the recognition of expenses in the commercial reporting is slower than the recognition of expenses for tax reporting or, in other words, the recognition of income for accounting purposes (Amelia \& Yudianto, 2016; Suandy, 2011).

This research's results sustained the hypothesis that permanent differences did not moderate the relationship between profitability and earnings management. Permanent differences occur because income and expenses are recognized commercially but not fiscally, for example, deposit interest (Brolin \& Rohman, 2014b).

This research confirmed the hypothesis that temporary differences moderated the effect of profitability on earnings management. Temporary differences occur due to differences in the timing recognition of income and expenses between taxes and accounting (Brolin \& Rohman, 2014b).

\section{CONCLUSION}

Research data were collected from 65 manufacturing companies listed on the Indonesian Stock Exchange during 2017-2018, so the total research sample was 130 (65 companies within two years of observation). The regression results indicate that tax planning has a negative but significant effect on earnings management. Tax planning carried out by the company is not the only strategy for corporate earnings management.

Profitability has a positive and significant effect on earnings management. Higher corporate profits will increase earnings management, consistent with the hypothesis proposed in this research. Permanent differences do not moderate the relationship between tax planning and earnings management, confirming the empirical results of the research hypothesis. Moreover, permanent differences do not moderate the relationship between profitability and earnings management, while temporary differences moderate the relationship between profitability and earnings management. It is also in line with the empirical results of the research hypothesis.

The researcher is aware that this study has limitations in the research data sample, which only involved the manufacturing companies listed on the 2017-2018 Indonesian Stock Exchange. Besides, the researcher has not examined the earnings quality variable.

Therefore, further studies are expected to use other variables to solve corporate agency problems, such as adding the earnings quality variable. When managers carry out earnings management by paying attention to Book-Tax Differences regarding tax planning and probability, the resulting earnings quality needs to be examined. Besides, further studies are suggested having different observation periods than in this study or extended examination periods, for example, five years of observation, to produce a better result.

The findings of this research have considerable managerial implications. For companies, it is hoped that corporate management can be more careful in including costs or 
expenses in earnings calculation intended to reduce calculations due to positive or negative fiscal corrections. The earnings management will have an impact on the financial reports if an error occurs. Potential investors should be more careful in making corporate investment decisions by assessing the earnings quality in several observation periods used as a proxy for accounting information quality.

\section{REFERENCES}

1. Aditama, F., \& Purwaningsih, A. (2016). Pengaruh Perencanaan Pajak Terhadap Manajemen Laba Pada Perusahaan Nonmanufaktur Yang Terdaftar Di Bursa Efek Indonesia. Modus. Https://Doi.Org/10.24002/Modus.V26i1.576

2. Agustina, A., Sulia, S., \& Rice, R. (2018). Faktor - Faktor Yang Mempengaruhi Profitabilitas Dan Dampaknya Terhadap Manajemen Laba. Jurnal Akuntansi, 22(1). Https://Doi.Org/10.24912/Ja.V22i1.320

3. Amelia, N., \& Yudianto, I. (2016). Pengaruh Book-Tax Differences Terhadap Kualitas Laba Dengan Manajemen Laba Sebagai Variabel Intervening. Jurnal Akuntansi Dan Keuangan, 16(1), 1-47

4. Amelia, W., \& Hernawati, E. (2016). Pengaruh Komisaris Independen, Ukuran Perusahaan, Dan Profitabilitas Terhadap Manajemen Laba. Neo Bis, 10(1), 62-77.

5. Brolin, A. R., \& Rohman, A. (2014). Issn_Pengaruh Book Tax Differences Terhadap Pertumbuhan Laba. Diponegoro Journal Of Accounting, 03(02), 1-13.

6. Damayanti, D., Syah, T. Y. R., \& Sunaryanto, K. (2019). Development Of Lean Consumption Concept In Improving Procurement Process Of New Item And Project Procurement. Russian Journal Of Agricultural And Socio-Economic Sciences, 92(8), 152-166.

7. Daniati, N. (2013). Pengaruh Book-Tax Differences Terhadap Pertumbuhan Laba Pada Perusahaan Yang Terdaftar Di Indeks LQ-45. Jurnal Audit Dan Akuntansi Fakultas Ekonomi Universitas Tanjungpura, 2(2), 75-104.

8. Fahmi, I., \& Saputra, M. (2013). Analysis Of Profitability Ratio In Publishing Right Issue Decision At Indonesia Stock Exchange. International Journal Of Business And Social Science, 4(4), 272-280.

9. Fitri, P. B. (2013). Pengaruh Ukuran Perusahaan, Leverage, Price Earning Ratio Dan Profitabilitas Terhadap Nilai Perusahaan. Jurnal Ilmu Manajemen, 1(1).

10. Gunawan, I. K., Darmawan, N. A. S., \& Purnamawati, I. G. A. (2015). Pengaruh Ukuran Perusahaan, Profitabilitas, Dan Leverage Terhadap Manajemen Laba. Jurnal Akuntansi Program S1 Universitas Pendidikan Ganesha, 03(1).

11. Hanlon, M. (2005). The Persistence And Pricing Of Earnings, Accruals, And Cash Flows When Firms Have Large Book-Tax Differences. In Accounting Review. Https://Doi.Org/10.2308/Accr.2005.80.1.137

12. Hapsari, D. P., \& Manzilah, D. (2016). Pengaruh Perencanaan Pajak Terhadap Manajemen Laba Dengan Arus Kas Operasi Sebagai Variabel Kontrol. Jurnal Akuntansi, $3(2)$.

13. Herawati, H., \& Ekawati, D. (2016). Pengaruh Perencanaan Pajak Terhadap Nilai Perusahaan. Jurnal Riset Akuntansi Dan Keuangan, 4(1), 873.

14. Hotimah, H. (2015). Pengaruh Perencanaan Pajak Terhadap Manajemen Laba. Esensi, 4(2).

15. Gunawan, I. K., Darmawan, N. A. S., \& Purnamawati I. (2015). Pengaruh Ukuran Perusahaan, Profitabilitas Dan Leverage Terhadap Manajemen Laba Pada Perusahaan Manufaktur Yang Terdaftar Di Bursa Efek Indonesia (BEI). E-Journal S1 Ak Universitas Pendidikan Ganesha, 03(01).

16. Kasmir. (2015). Pengertian Laporan Keuangan. Harahap, 2015(105).

17. Koch, B. S. (1981). Income Smoothing: An Experiment. The Accounting Review. ISSN:0001-4826

18. Limbong, R. P., Syah, T. Y. R., Anindita, R., \& Moelyono. (2019). Risk Management For Start-Up Company: A Case Study Of Healthy Kitchen Restaurant And Catering. Russian 
Journal Of Agricultural And Socio-Economic Sciences, 86, 267-272.

19. Munandar, A. (2014). Effects Of Size, Profitability, And Growth Rate Towards Capital Structure. Jurnal Dinamika Manajemen, 2(3).

20. Munandar, A., Meita, I., \& Putritanti, L. R. (2018). Pelatihan Pembukuan Dan Pencatatan Keuangan Sederhana Kepada Siswa/l Yayasan Prima Unggul. Jurnal Pengabdian Kepada Masyarakat, 24, 527.

21. Purnamasari, D. (2019). How The Effect Of Deferred Tax Expenses And Tax Planning On Earning Management? International Journal Of Scientific And Technology Research, 8(2), 78-83.

22. Ramdhani, D. (2016). Analisis Faktor-Faktor Yang Mempengaruhi Tingkat Pengungkapan Laporan Keuangan Pemerintah Daerah Di Propinsi Banten. Jurnal Riset Akuntansi Terpadu, 9.

23. Rasinih, R., \& Munandar, A. (2016). Pengaruh Financial Leverage Dan Profitabilitas Terhadap Income Smoothing Dengan Kualitas Audit Sebagai Pemoderas. Jurnal IImiah Akuntansi Dan Bisnis.

24. Riska, N. S., Arief, T. H., \& Patar, S. (2019). Pengaruh Beban Pajak Tangguhan, Perencanaan Pajak Dan Profitabilitas Terhadap Manajemen Laba Pada Perusahaan Manufaktur Yang Terdaftar Di Bursa Efek Indonesia Periode 2012-2017. Jurnal Online Mahasiswa Bidang Akuntansi, 5(5).

25. Sari, D., \& Lyana, I. D. D. (2015). Book Tax Differences Dan Kualitas Laba. Jurnal Akuntansi Multiparadigma, 6(3).

26. Sari, D. P., \& Purwaningsih, A. (2016). Pengaruh Book Tax Differences Terhadap Manajemen Laba. Modus. DOI:10.24002/modus.v26i2.583. ISSN:0852-1875

27. Schipper, K. (1989). Earning Management. Accounting Horizons, 3, 91-106.

28. Suandy, E. (2011). Perencanaan Pajak ( $5^{\text {th }}$ Ed). Jakarta: Salemba Empat.

29. Watts, R., \& Zimmerman, J. (2006). Positive Accounting Theory: A Ten Year Perspective. Accounting Review. ISSN: 00014826, PMID: 9603274032

30. Yuniati, D. S. A. L., Kurnia, I., \& Yuniati. (2018). Pengaruh Perencanaan Pajak Dan Ukuran Perusahaan Terhadap Manajemen Laba (Studi Empiris Pada Perusahaan Manufaktur Yang Terdaftar Di Bursa Efek Indonesia Periode 2015-2017). Jurnal Ilmiah MEA (Manajemen, Ekononi, \& Akuntansi), 2(3) 129-150.

31. Yunila, F., \& Aryati, T. (2018). Pengaruh Perencanaan Pajak Dan Pajak Tangguhan Terhadap Manajemen Laba Dengan Kualitas Audit Sebagai Variabel Moderasi. Seminar Nasional Cendekiawan, (1981), 1021-1027. 